\title{
THE RELIGIOSITY OF THE INDONESIAN CONSTITUTION: ARTICLE 29(1) AND ITS INTERPRETATION
}

\author{
Ahmad Rofii ${ }^{*}$ \\ State Institute of Islamic Studies (IAIN) \\ Syekh Nurjati Cirebon, Indonesia \\ arofii@syekhnurjati.ac.id
}

Received: 28 September 2021 | Last Revised: 28 November 2021 | Accepted: 2 December 2021

\begin{abstract}
This paper examines the problem of whether the inclusion of religious words in the Indonesian Constitution is tantamount to the establishment of a religious constitution. By focusing on the Constitution's provision on "belief in the One and Only God" in Article 29(1), this paper challenges the received theory of the religiosity of the Constitution. To that end, the paper first investigates the doctrinal and historical implications of Article 29(1). Particular analysis concerns the implications of this constitutionalization for Islamic law. The Constitutional Court's decision on interreligious marriage is critically examined as an example of how the received theory is endorsed and articulated in the case of marriage. This paper argues that Article 29(1) concerns all religions, without any implied exclusion of non-monotheistic religions. Moreover, this paper affirms what is called the Pancasila state, located between an exclusively secular state and a religious or theocratic state. This arguably makes the notion of the religiosity of the Constitution unjustified. The Constitutional Court, however, has interpreted Article 29(1) in a strongly religious sense, leading to religious supremacy and, accordingly, is contrary to how the Constitution ought to be understood.
\end{abstract}

Keywords: Article 29(1), Constitutional Court, Indonesian Constitution, Interreligious Marriage Case, Pancasila.

Senior lecturer at the State Institute for Islamic Studies (IAIN) Syekh Nurjati Cirebon, West Java. The author is grateful to Nadirsyah Hosen, Patrick Emerton, and Luke Beck for their invaluable feedback and insightful suggestions on an early draft of this article. The author would also like to thank the anonymous reviewers for their helpful comments. 


\section{INTRODUCTION}

The amendment of the 1945 Constitution over 1999-2002 had a significant impact on the place of religion in Indonesia. A number of provisions containing references to religion were inserted, including religious values, iman (faith) and takwa (piety), religious judiciary, and legislation of religion. Together with the readoption of the principle 'belief in the One and Only God' (Ketuhanan Yang Maha Esa) ${ }^{1}$ in the Preamble to the Constitution and Article 29(1), this 'new' constitutionalism has been considered as establishing what can be called a 'Godly constitutionalism'. In line with this, four of the nine justices of the Constitutional Court in 2016, in response to a petition to ban extramarital sex, suggested the constitutional principle of belief in the One and Only God requires that all legislation and case law should be "illuminated by religious values and divine light". ${ }^{2}$ With such significant reference to religion, can the 1945 Constitution be meaningfully categorized as a religious constitution? What would this categorization imply?

This paper examines whether the Constitution's references to belief in God constitute the establishment of a religious constitution. 'Religious constitutionalism' is used here as a category distinct from its rival, 'secular constitutionalism'. While the latter establishes the institutional separation of state and religion, the former makes religion(s) the basis of government. Secular constitutionalism has two different models: the first excludes and is hostile to religion, while the second is benevolent and inclusive of religion. ${ }^{3}$ On the other hand, religious constitutionalism establishes a religion or some religions as the only state-recognized religion(s). A religious constitution might take the form of strong or moderate religiosity. In a strong religious constitution, religion has determinate authority in matters of public life. What might be called 'theocratic constitutionalism' is based on the idea of the rule of religious law or norms. ${ }^{4}$ Conversely, a moderate religious constitution is a constitution which endorses and establishes religion(s) by law but is highly supportive of religious freedom.

Ketuhanan Yang Maha Esa is sometimes translated in English as 'belief in One Supreme God' and 'belief in the One Almighty God'. This paper uses 'belief in the One and Only God', as per the Indonesian government's official translation of the 1945 Constitution.

2 Judicial Review of Criminal Law, Decision of Constitutional Court No. 46/PUU-XIV/2016 (The Constitutional Court of the Republic of Indonesia, 2017).

3 RexAhdar and lan Leigh, Religious Freedom in the Liberal State, 2nd ed. (Oxford: Oxford University Press, 2013), 95-97.

4 Larry Catá Backer, "Theocratic Constitutionalism: An Introduction to a New Global Legal Ordering," Indiana Journal of Global Legal Studies 16 (2009): 85. 
By focusing on Article 29(1), this paper challenges the received theory of the religiosity of the 1945 Constitution. To this end, the paper first investigates the doctrinal and historical implications of Article 29(1). It then critically analyzes the Constitutional Court's decision in the Interreligious Marriage Case as an example of how the received theory is endorsed and articulated in the case of marriage. In this paper, I argue that Article 29(1) refers to all religions equally. Article 29(1) establishes a middle way of state-religion relations, that is, a state which endorses neither the strict separation of state and religion nor the supremacy of religion as in theocratic constitutionalism. It is arguably unjustified then to assume the religiosity of the Constitution. However, the Constitutional Court's interpretation of Article 29(1), as in the Interreligious Marriage Case, adopts religious supremacy. This case demonstrates a gap between how the Constitution ought to be understood and its authoritative interpretation by the Constitutional Court.

\section{ARTICLE 29(1): THE CONSTITUTIONAL SIGNIFICANCE OF BELIEF IN GOD}

Article 29 of Chapter XI on religion covers the thorny issue of state-religion relations. Article 29 states:

(1) The state is based upon the belief in the One and Only God;

(2) The state guarantees the freedom of religion for each citizen and to practice such religion and belief accordingly.

The wording and authority of Article 29 have led to ongoing controversy over the appropriate role of religion in Indonesia. It raises issues such as what counts as religion, how state-religion relations might be justified in line with the article, and the legal implication of 'belief in the One and Only God'. Owing to its ambiguity, Article 29 has so far been adopted as a locus of constitutional legitimacy for competing views on the state enforcement of religious law. In the following paragraphs, Article 29(1) is examined in terms of its creation in 1945 and its readoption during the amendment process more than 50 years later. Through this examination, it becomes clear how the article was articulated differently in both constitutional periods, and how the differences, in particular between the Islamist and secular-nationalist factions, colored its creation and adoption. 


\subsection{Article 29(1) of the Original Constitution}

The first formal draft of the Indonesian Constitution made no reference to belief in God. The draft version of Article 29 in the section 'On Religion' (Tentang Agama) consisted of only one paragraph, providing a state guarantee of religious freedom. It read, "The State guarantees the freedom of every resident to profess any religion [agama apapun] and to worship according to his/her own religion." This article was the same as a rough draft of a provisional constitution proposed nearly a month earlier on 15 June 1945 by a seven-member group led by Husein Djajadiningrat and including Supomo. ${ }^{5}$

On 22 June 1945, a 'Committee of Nine' of the drafters drew up a draft preamble to the constitution. This draft preamble was called the Jakarta Charter. It included the five principles of the state ideology, Pancasila, but the first principle contained an additional 'seven words' effectively stating that Muslim citizens would be required to follow Islamic law: "dengan kewajiban menjalankan Syariat Islam bagi pemeluk-pemeluknya [with the obligation to carry out Islamic Sharia for its adherents]".

During the debates among the Investigating Committee for the Preparation for Indonesian Independence (Badan Penyelidik Usaha Persiapan Kemerdekaan Indonesia, BPUPKI) on 13 July 1945, Otto Iskandardinata suggested a revision to the draft constitution's Article 29, so the article would consist of two paragraphs: the first to contain the first principle of the Jakarta Charter, namely, "belief in God, with the obligation to carry out Islamic Sharia for its adherents", and the existing single paragraph on religious freedom to be placed second. ${ }^{6}$

The Constitutional Drafting Committee accepted this suggestion, with revisions. The paragraph on "belief in God" appeared in the second draft, Chapter X on Religion, now as Article 28(1), which read, "The State shall be based on the belief in God with the obligation to perform religious rituals [ibadah]." Before this latest draft was discussed, the Drafting Committee proposed another revision of the first paragraph, which then read, "The

A.B. Kusuma, ed., Lahirnya Undang-Undang Dasar 1945: Memuat Salinan Dokumen Otentik Badan Oentoek Menyelidiki Oesaha2 Persiapan Kemerdekaan [the Birth of the 1945 Constitution: Containing Copies of Authentic Documents of the Investigating Committee for the Preparation for Indonesian Independence], revised (Jakarta: Badan Penerbit Fakultas Hukum Universitas Indonesia, 2009), 195 (Article 14 'On Religion').

6 Kusuma, 314-15. 
State shall be based on the belief in God, with the obligation to carry out Islamic Sharia for its adherents." Here, the draft inserted the 'seven words' of the Jakarta Charter. In Supomo's explanation, this new phrase was a further step in accommodating Islamic law, after it was adopted in the draft preamble. As was the case with the Jakarta Charter, the draft paragraph was also agreed to by both the Islamist and secular nationalist representatives in the Committee. ${ }^{7}$ Meanwhile, the numbering of the section on religion was reverted to Article 29, while the chapter number was altered to XI.

Despite the initial acceptance of the textual revision, a meeting of the Preparatory Committee for Indonesian Independence (Panitia Persiapan Kemerdekaan Indonesia, PPKI) on 18 August 1945 replaced the 'seven words' with "Yang Maha Esa [the One and Only (God)]". With this change, the final version of Article 29 was unanimously accepted.

The adoption of Chapter XI and Article 29 resulted in there being no clear significance of the word 'religion' and the phrase 'belief in the One and Only God'. The inclusion of the latter phrase and the exclusion of the 'seven words', in both Pancasila and the Constitution, was not reached with wholehearted agreement by the nation's founding fathers. In particular, the Islamists' aspiration for shariah law was dismissed. As a modus vivendi, Article 29 would have been understood differently by the framers, who had diverse religious affiliations and ideological perspectives. Mohammad Yamin, employing a systematic interpretive method, proposed a restrictive interpretation, to the effect that 'religion', as the title of the chapter, meant 'monotheistic religion', consistent with Paragraph 1 of the article. 9

However, the fact that the word 'religion' was chosen as an all-inclusive term, agreed to by all the framers, would suggest it should include all faiths and religions, as might have been expected by the framers and the general public. Moreover, the phrase 'belief in the One and Only God' does not necessarily mean a monotheistic belief. The adoption of the words 'One and

Hadikusumo, while agreeing to the seven words of the preamble, objected to their adoption in paragraph 1 of the article because of their ambiguity. This is probably related to his previous suggestion to remove the words 'bagi pemeluk-pemeluknya [for its adherents]' so that Islamic sharia would bind everyone, not only Muslims. Kusuma, 413-15.

8 Kusuma, 471.

9 Mohammad Yamin, Pembahasan Undang-Undang Dasar Republik Indonesia [Commentary on the Constitution of the Republic of Indonesia] (Jakarta: Jajasan Prapantja, 1960), 523. 
Only' as the replacement of the 'seven words' signified a reluctant agreement, and therefore suggests that their legitimate importance was more sociological than legal. What was fundamental in the paragraph, therefore, centered on the term 'belief in God' (Ketuhanan), another expression of religion which suggested inclusive understanding.

The constitutional arrangement of God and religion in Article 29, together with the Preamble's five principles (Pancasila), has conventionally been regarded as the basis for identifying Indonesia's approach to state-religion relations as a middle way, combining both secular and Islamist visions. Founding president Sukarno's speech on Pancasila as the foundation of the state, delivered to the BPUPKI, was evidence of this approach. ${ }^{10}$ During Suharto's New Order regime (1965-98), this middle way was then characterized as being neither secular nor theocratic. ${ }^{11}$ Instead of belonging to either of the dichotomic alternatives, Indonesia was viewed as a state based on the "belief in the One and Only God', exactly as may be read from the first paragraph of Article 29. In this model of state-religion relations, limited religious norms and laws might be incorporated by the state. The omission of the 'seven words' from the first paragraph, therefore, could not be interpreted as barring Islamic law from being part of the state legal system. The reason for this omission was mostly the implication for unequal treatment of the existing religions, by giving preference to Islam, rather than because of any objection to state incorporation of religious norms, as such.

From the wording of Article 29(1), one might assume the belief in 'the One and Only God' is the sole, or supreme basis, of the state, which corresponds with the belief in the superiority of the first principle of Pancasila. This would imply, as Hazairin has argued, that state policies, in general, should not contravene religious norms, and that the state should enforce religious laws for its adherents. ${ }^{12}$ However, the structure of the Constitution does not support this interpretation. Article 29 is part of Chapter XI on religion, signifying that the meaning of a 'basis for the state' would be conceivable

Kusuma, Lahirnya Undang-Undang, 156.

${ }_{11}$ This 'neither-nor' approach aimed to maintain unity and harmony. For a critical analysis of this approach, see Eka Darmaputera, Pancasila and the Search for Identity and Modernity in Indonesian Society: A Cultural and Ethical Analysis (Leiden: E. J. Brill, 1988), 183-221.

12 Hazairin, Demokrasi Pantjasila [Pancasila Democracy] (Jakarta: Tintamas, 1970), 18-19. 
only in the context of religion. In other words, the article would suggest that in terms of religion, the state is based on the belief in the One and Only God. There are principles which might also be considered as bases of the state, other than that of religion. It may be argued that this religious basis constitutes part of the foundation of the state, Pancasila, as enshrined in the last paragraph of the Preamble. Article 29(1), therefore, suggests only $a$ basis, not the only basis, of the state. Consequently, being only a basis of the state, the 'belief in the One and Only God' should not have a conclusive role in determining state laws and policies.

\subsection{Article 29(1) in the Amendment Process}

In the constitutional amendment process of 1999-2002, discussions of religion must be viewed within the context of the previous and existing discursive practices of religion in Indonesia. The debates between members of the People's Consultative Assembly (Majelis Permusyawaratan Rakyat, MPR) on the amendment to Article 29 demonstrate this diverse understanding of the nature of constitutional 'religion', the significance of 'belief in the One and Only God', and how all of these subjects might be determined and regulated by the state. Although the result of the process was the unchangeability of the article, the debates shed some light on its significance regarding the legitimacy of the state support of religion.

The complexity of religious issues, and the opacity of the roles of religion, led some members of the MPR, in the early years of the amendment process, to suggest the need for constitutional clarity on the status of religion and its relation to 'belief in the One and Only God' as according to Article 29. ${ }^{13}$ However, while members of the MPR seemed to agree on the importance of religion, and the centrality of belief in the One and Only God, in the life of the state, no attempt at agreement was seriously attempted on what the Constitution meant by 'religion'. The amendment drafters' different views on these matters were evident in the debates on whether Article 29 should be amended.

\footnotetext{
-3 Majelis Permusyawaratan Rakyat Republik Indonesia [People's Consultative Assembly], Risalah Perubahan UndangUndang Dasar Negara Republik Indonesia Tahun 1945: Tahun Sidang 2000, Buku Satu [Minutes of the Amendment of the 1945 Constitution of the Republic of Indonesia: Meeting Year 2000, Book One], revised (Jakarta: Sekretariat Jenderal, 2010), 79 (Hobbes Sinaga of F-PDIP).
} 
Secular nationalist factions of the MPR, including the Indonesian Democratic Party of Struggle faction (Fraksi Partai Demokrasi IndonesiaPerjuangan, F-PDIP) and the Indonesian Armed Forces and National Police faction (Fraksi Tentara Nasional Indonesia/Kepolisian Republik Indonesia, F-TNI/POLRI), and the Christian-based Love the Nation Democratic Party faction (Fraksi Partai Demokrasi Kasih Bangsa, F-PDKB) insisted on upholding the original article and securing it from any amendment. In contrast, two Islam-oriented factions, the Crescent Moon and Star Party faction (Fraksi Partai Bulan Bintang, F-PBB) and the United Development Party faction (Fraksi Partai Persatuan Pembangunan, F-PPP), proposed and consistently argued for the reinstatement of the 'seven words' of the Jakarta Charter, suggesting that Paragraph 1 of Article 29 should read, "The state shall be based on the belief in the One and Only God, with an obligation to carry out Islamic Sharia for its adherents." The Union of Muslim Sovereignty faction (Fraksi Perserikatan Daulat Umat, F-PDU) at first proposed a slight change to Paragraph 2 of Article 29, as did the faction of the Interest Groups Representatives (Fraksi Utusan Golongan, F-UG), in which the word 'belief' was to be omitted, but the former later joined the stance of F-PBB and F-PPP. Other factions, including the National Awakening Party faction (Fraksi Kebangkitan Bangsa, F-KB), Golkar Party faction (Fraksi Partai Golkar, F-PG), the Reform Faction (Fraksi Reformasi, F-Reformasi) and Indonesian National Unity faction (Frasksi Kesatuan Kebangsaan Indonesia, F-KKI), suggested a different additional paragraph. ${ }^{14}$

The long-lasting, heated debates on the amendment to Article 29 revealed three different viewpoints. First, was the Islamist factions' proposal to add

${ }_{14}$ On the polarization between the MPR factions on the amendment of the Article 29 and the various proposals for the amendment, see Umar Basalim, Pro-Kontra Piagam Jakarta di Era Reformasi [Pros and Cons of the Jakarta Charter in the Reform Era] (Jakarta: Pustaka Indonesia Satu, 2002); Tim Penyusun Naskah Komprehensif Proses dan Hasil Perubahan UUD 1945 [Drafting Team of the Comprehensive Text of the Processes and Results of the Amendment of the 1945 Constitution], Naskah Komprehensif Perubahan Undang-Undang Dasar Negara Republik Indonesia Tahun 1945: Latar Belakang, Proses, dan Hasil Pembahasan 1999-2002, Buku VIII Warga Negara dan Penduduk, Hak Asasi Manusia dan Agama [Comprehensive Text of the Amendment of the 1945 Constitution of the Republic of Indonesia: Background, Processes, and Debates Results 1999-2002, Book VIII Citizens and Population, Human Rights and Religion], revised (Jakarta: Sekretariat Jenderal dan Kepaniteraan Mahkamah Konstitusi, 2010), 88-107; Valina Singka Subekti, Menyusun Konstitusi Transisi: Pergulatan Kepentingan dan Pemikiran Dalam Proses Perubahan UUD 1945 [Drafting the Transitional Constitution: The Struggle of Interest and Ideas in the Process of the Amendment of the 1945 Constitution] (Jakarta: PT RajaGrafindo Persada, 2008), 147-166; Nadirsyah Hosen, Shari'a and Constitutional Reform in Indonesia (Singapore: ISEAS, 2007), chap. 6; R.E. Elson, "Two Failed Attempts to Islamize the Indonesian Constitution.," SOJOURN: Journal of Social Issues in Southeast Asia 28, no. 3 (November 2013): 405-20. 
the 'seven words' to the existing first paragraph. Its supporters relied on the significance of the Jakarta Charter, as well as a conciliatory assurance made by Sukarno in 1959 that he had depended on the Jakarta Charter when issuing a decree that reinstated the 1945 Constitution, and also the religious consideration of the obligation for Muslims to carry out Islamic law. ${ }^{15}$ This view marked a second revival of efforts to restore the 'seven words', after the first one during the Constituent Assembly debates of post-1945 Islamist aspirations. What differentiated the contemporary Islamist perspective from that of its predecessors is the weak demand of the former for constitutional Islamization. In the pre-constitutional amendment period, the Islamist groups kept supporting the idea of an Islamic state, according to the ideals of strong religious constitutionalism, whereas during the amendment process, having accepted the reality of the Pancasila state, they demanded only the adoption of the 'seven words'.

Second, some Islam-based factions maintained that Article 29 was a national consensus and considered it a common platform (kalimah sawa') that remained compatible with the demands of Islam. Although it was not religiously ideal, the article could still be relied on to advance their Islamic objectives. ${ }^{16}$ Despite their difference concerning the inclusion of the 'seven words', both this view and the Islamist perspective shared a similar concern in furthering religious interests. By reference to the Islamic worldview, such as that of the compatibility of Paragraph 1 with the principle of tawhid (Islamic monotheism), the second perspective saw Article 29 as supporting the application of religious precepts. Harifuddin Cawidu of the F-UG made an unqualified religious argument for supporting this article, as he propounded what he called the "cultural-substantive" view of Islam, which meant that although sharia was not enshrined in it, the current Constitution remained religiously legitimate, because, under this Constitution, Islamic law in general could be applied by Muslims. ${ }^{17}$

\footnotetext{
15 See the pro-Jakarta Charter arguments (F-PDU, F-PBB, and F-PPP) in Majelis Permusyawaratan Rakyat Republik Indonesia, Risalah Perubahan Undang-Undang Dasar Negara Republik Indonesia Tahun 1945: Tahun Sidang 2002, Buku Lima [Minutes of the Amendment of the 1945 Constitution of the Republic of Indonesia: Meeting Year 2002, Book Five], revised (Jakarta: Sekretariat Jenderal, 2010), 640, 642, 649, 667-70.

16 This was the view of the F-Reformasi and F-KB. See Majelis Permusyawaratan Rakyat Republik Indonesia, 661, $665-6,693$.

${ }_{17}$ Majelis Permusyawaratan Rakyat Republik Indonesia, 240.
} 
Third, the secular-nationalist factions, which wanted Article 29 to be unchanged, argued the article was the ideal arrangement for state-religion relations. It was a meeting point for differences of religion and belief, which remained relevant. The concerns and justifications were mostly on the primacy of national integrity, unity and harmony amid diversity. ${ }^{18}$ These were also the concerns of the first generation of the secular-nationalist group, during the 1945 constitution-making.

The Islamist demands for the inclusion of the 'seven words' failed to receive wide acceptance among the members of the MPR. Nevertheless, the Islamist factions and some members of other factions insisted on their appeal, and eventually did not take part in the readoption of the original Article 29. ${ }^{19}$ The readoption of the article by the majority, and the decline in the influence of the Islamist factions and members, demonstrated the different paths the latter have taken from those of their predecessors in the 1945 constitution-making process, who were able to accept the article, regardless of the removal of the 'seven words'. It is not clear whether the contemporary Islamists' abstention from adopting the article suggests the reference to God in Paragraph 1 could not be religiously justified by reference to the principle of tawhìd, as had been advocated by many other Muslim members, and as the Islamist framers of the 1945 Constitution previously believed.

The readoption of Article 29 gives rise to some implications for a proper understanding of the reference to God and religion in the article. First, despite the failure of the Islamist proposal, most if not all factions of the MPR agreed that Article 29 affirms the middle way of the Indonesian model of state-religion relations. The agreement was a re-statement of the wide consensus, long held before the amendment process, as mentioned earlier. For the drafters of the amendments, the Pancasila state, or a state based on 'the belief in the One and Only God', was to be understood as located between a secular and a theocratic state. In other words, it was neither an exclusively secular state nor a strong religious state. It was a state which

18 This was the argument of F-KKI, F-TNI/Polri, and F-PDIP. See Majelis Permusyawaratan Rakyat Republik Indonesia, $645,656,681$.

19 Majelis Permusyawaratan Rakyat Republik Indonesia, 690 (F-PPP), 691 (F-PBB), 691-2 (F-PDU), $692-5$ (some members of F-Reformasi and F-UG). 
gave significant roles to religion, by facilitating and encouraging religious observance; ${ }^{20}$ all religions could live in harmony guaranteed by law. ${ }^{21}$

The Pancasila state is therefore the opposite of states having the nonestablishment of religion, such as France, Turkey and the United States. ${ }^{22}$ It is also contrary to states with the supremacy of religious law, or so-called constitutional theocracy, ${ }^{23}$ such as Iran, Egypt and Afghanistan. ${ }^{24}$ Some members of the MPR, however, argued for a stronger religious implication to be drawn from Article 29, contending that, as a consequence of Paragraph 1, no state policies should contradict religious values, norms or provisions. ${ }^{25}$ Since this view tends to support a theocratic ideal, or strong religious constitutionalism, by establishing the supremacy of religious law, it would constitute a denial of the Pancasila state as a middle-way state. Most members of the MPR agreed that, despite its support of religious institutions and its incorporation of religious norms, the Pancasila state was not a theocratic state. ${ }^{26}$

Second, the MPR members from the Islamist factions seemed to agree that although the state was not based on one religion, Paragraph 1 was indicative of a preference in favor of a limited number of religions, that it restricted the constitutionally recognized religions to monotheistic religion(s). ${ }^{27}$ From

20 Majelis Permusyawaratan Rakyat Republik Indonesia, Risalah Perubahan Undang-Undang Dasar Negara Republik Indonesia Tahun 1945: Tahun Sidang 2000, Buku Lima [Minutes of the Amendment of the 1945 Constitution of the Republic of Indonesia: Meeting Year 2000, Book Five], revised (Jakarta: Sekretariat Jenderal, 2010), 410, 424 (Harun Kamil), 412 (Asnawi Latief, F-PDU), 421 (Rosnaniar, F-PG), 443 (Ali Masykur Musa, F-KB).

${ }_{21}$ Majelis Permusyawaratan Rakyat Republik Indonesia, Risalah Perubahan Undang-Undang Dasar Negara Republik Indonesia Tahun 1945: Tahun Sidang 2000, Buku Tujuh [Minutes of the Amendment of the 1945 Constitution of the Republic of Indonesia: Meeting Year 2000, Book Seven], revised (Jakarta: Sekretariat Jenderal, 2010), 24 (Hajriyanto Y. Thohari, F-PG).

22 Constitution of France, Art. 1; Constitution of the Republic of Turkey, Art. 2; United States Constitution, Amend. I. On different models of the separation in these three constitutions, see Ahmet T. Kuru, Secularism and State Policies toward Religion: The United States, France and Turkey (New York: Cambridge University Press, 2009).

23 Ran Hirschl, Constitutional Theocracy (Cambridge, Mass.; London: Harvard University Press, 2010); Backer, "Theocratic Constitutionalism: An Introduction to a New Global Legal Ordering."

24 Constitution of the Islamic Republic of Iran, Art. 4; Dustūr Jumhūriyyah Mișr Al-'Arabiyyah [Constitution of the Arab Republic of Egypt], Art. 2; Constitution of the Islamic Republic of Afghanistan, Art. 3. In one sense, there is similarity between the Indonesian Constitution and the Iranian Constitution (Article 2) in their reference to 'One Supreme God' as a basis of the state.

25 Majelis Permusyawaratan Rakyat Republik Indonesia, Tahun Sidang 2000, Buku Lima, 422 (Rosnaniar, F-PG). This view is similar to that of Hazairin. See note 11 above. See also Jeroen Temperman, State-Religion Relationships and Human Rights Law: Towards a Right to Religiously Neutral Governance (Leiden and Boston: Martinus Nijhoff Publishers, 2010), 30-31 (arguing that Indonesia, based on Article 29, is a monotheist state).

26 In his introductory comments before a meeting on Article 29 in 2000, Harun Kamil suggested the Pancasila state should not interfere too much in the internal affairs of religion. See Majelis Permusyawaratan Rakyat Republik Indonesia, Tahun Sidang 2000, Buku Lima, 410.

${ }_{27}$ Majelis Permusyawaratan Rakyat Republik Indonesia, 468 (Lukman Hakim Saifuddin, F-PPP). 
an Islamic point of view, as believed by many Muslim members, Paragraph 1 was justifiably accepted, for the reason that it corresponded with the principle of Islamic monotheism (tawhìd). ${ }^{28}$ This correspondence, however, needed not imply any restriction on the state recognition of religion. Read together with the agreement that the Pancasila state was not a theocratic state, this would mean, as many members also held, that there was no official religion or religions, and that restricting the definition of religion to only a few recognized religions was, accordingly, constitutionally unfounded. ${ }^{29}$ Furthermore, as argued earlier, in the light of its drafting and adoption history, the main point in Paragraph 1 was not the phrase 'One and Only (Yang Maha Esa)' but rather that of 'belief in God (Ketuhanan)'. The addition of 'One and Only' was a political compromise, which conveyed a mere symbolic value. It was 'belief in God' which was unanimously agreed upon by the framers, and so had interpretive significance. This phrase is arguably a general reference to religion. This would mean that Paragraph 1 concerns all religions, without any implied exclusion of non-monotheistic religions.

Regarding the consequences of the readoption of the original Article 29 for the legitimacy of the state incorporation of religious law, particularly Islamic law, it seems clear that the failure to incorporate the 'seven words' did not undermine the acceptability of state-enacted Islamic law, for the drafters of the amendments. It has been argued that Paragraph 1 of Article 29 makes 'belief in the One and Only God' a basis of the state, with the effect that the state must take the belief/religion, in addition to other bases, seriously in its policies. Furthermore, Paragraph 2 of Article 29 stipulates the state must guarantee both the freedom to hold a religion and to practice it (worship). State enforcement of Islamic law could, accordingly, be considered an application of Article 29, in the interests of Muslims. It is likely, by way of this sort of reasoning, that the MPR factions established the legitimacy of Islamic law. The secular-nationalist F-TNI/POLRI clearly suggested that "Islamic Sharia can be constitutionally and culturally applied, in accordance

${ }_{28}$ Majelis Permusyawaratan Rakyat Republik Indonesia, 412 (Asnawi Latief, F-PDU); Majelis Permusyawaratan Rakyat Republik Indonesia, Tahun Sidang 2002, Buku Lima, 225 (M. Anwar Iskandar, F-KB), 229 (Amidhan, F-PG), 249 (Yusuf Muhammad, F-KB), 252 (Achmad Aries Munandar, F-PDIP).

29 Majelis Permusyawaratan Rakyat Republik Indonesia, Tahun Sidang 2000, Buku Lima, 429 (Amidhan, F-PG), 458 (Yusuf Muhammad, F-KB). 
with the Presidential Decree on the Constitution of the 1959".30 Even the Christian-nationalist F-PDKB could still accept legislative enactment of Islamic law, albeit while strongly resisting its constitutionalization. ${ }^{31}$

The previous discussion on Article 29(1) demonstrates how the drafters of the article acknowledged the legitimacy of state incorporation of religious law, Islamic law in particular. Such acknowledgment was a consequence of having 'belief in the One and Only God' as a state basis in terms of religion. Being a state basis, this principle in no way legitimizes the establishment of religious constitutionalism, in which religious values and norms become the supreme principle and law, because such establishment would be contrary to the idea and ideals of the Pancasila state.

\section{THE INTERRELIGIOUS MARRIAGE CASE}

How is the belief in the One and Only God interpreted and articulated in constitutional cases? How has the Constitutional Court, as the most authoritative interpreter of the Constitution, viewed any implication of Article 29(1) for the religious character of the Constitution? In the following paragraphs, this paper offers an answer to these questions through a critical analysis of the Court's decision to hold the constitutionality of Article 2(1) of Law No. 1 of 1974 on Marriage (the Marriage Law).

\subsection{Case Background}

The Marriage Law sets the religious foundation of marriages in Indonesia. As provided in Article 2(1), the validity of marriage is determined by the respective religious laws of the marrying couples. The law is silent on the status of interreligious or interfaith marriages. Since the promulgation of the law, interreligious marriage has been subject to different, even conflicting, treatments by the government. The case brought before the Constitutional Court concerning the constitutionality of Article 2(1) was mainly motivated by the impact of this provision on the legitimacy of interreligious marriage.

Article 2 is the backbone of the Marriage Law, in matters relating to the validity of marriages. It differs substantially from its first draft. In the

30 Majelis Permusyawaratan Rakyat Republik Indonesia, Tahun Sidang 2002, Buku Lima, 239 (Abdul Rachman Gaffar).

${ }^{31}$ Majelis Permusyawaratan Rakyat Republik Indonesia, Tahun Sidang 2000, Buku Lima, 435 (Gregorius Seto Harianto). 
Marriage Law, the validity of a marriage is determined by its conformity with religious requirements; whereas the bill had adopted the civil marriage model and, as such, the validity of marriage was determined by being registered and performed according to the law (draft Article 2(1)). In terms of religion, draft Article 11(2) even provided that "differences of nationality, race, countries of origin, places of origin, religion/belief and descent are not impediments to marriage". This clearly meant that interreligious marriages would be legitimate. The final draft of the Marriage Law, however, deleted Article $11 .{ }^{32}$ The provision on the validity of marriage was also changed, so that it covered not only mandatory registration but, most importantly, religious determination.

The Marriage Law shows strong religious influence in many of its provisions. The law, as its General Elucidation states, "contains elements and provisions of the laws of the respective religions and beliefs." 33 In Article 1, which differs slightly from its draft wording, the definition of marriage is linked to 'belief in the One and Only God' as the basis of a family. This would mean, as the elucidation of the article asserts, that "marriage is closely related to religion/spirituality, so that marriage has not only outer/physical aspects, but also inner/spiritual aspects, which also play an important role".

Article 2 not only requires marriage registration, but most fundamentally defers determination of the validity of a marriage to the dictates of religion and belief. It stipulates:

(1) A marriage is legitimate, if it has been performed according to the laws of the respective religions and beliefs of the parties concerned;

(2) Every marriage shall be registered according to the legislation and regulations in force.

The elucidation of Article 2 states that, in line with the Constitution, there will not be a legitimate marriage performed outside the bounds of the laws of the respective religions and beliefs. Inclusive of the laws of the religions and beliefs are all pieces of legislation and regulations applicable to the respective religious believers and adherents to beliefs. As stipulated in the General Elucidation, the provision in this article constitutes one of

32 On the controversy on draft Article 11, see Mujiburrahman, Feeling Threatened: Muslim-Christian Relations in Indonesia's New Order (Amsterdam University Press, 2006), 177-79.

33 Law No. 1 of 1974 on Marriage, General Elucidation No. 3. 
the fundamental principles underlying the law. By requiring conformity with religions and beliefs, the article rejects the bill's concept of marriage as being merely a civil relationship. It is this provision which was specifically drafted to accommodate Islamic demands.

Although the text provides for religious determination, as described above, the Marriage Law does not subject every aspect of marriage validity to religion alone. This is because the applicable laws of religion and belief remain constrained by state law. ${ }^{34}$ Religions and religious laws vary, and there is a plurality of religious interpretations of those laws. Some interpretations may contradict the principles underlying the state law. The Marriage Law itself can be conceived of as a state limitation on these religious interpretations. For instance, the law limits the authority of religions, in cases concerning the validity of polygamy (Articles 4 and 5$)^{35}$ and of underage marriages (Articles 6 and 7)..$^{6}$

It has been disputed whether the laws of religion and belief alone determine the validity of a marriage, in accordance with Paragraph 1 of Article 2, or if its validity will also be determined, in line with Paragraph 2 , by it being registered. The majority view is that the validity of marriage is determined by its compliance with religious laws, while the provision for marriage registration merely concerns an administrative requirement. Some scholars, however, consider the two paragraphs as inseparable, so that a marriage is legitimate only if it is consistent with the law of religion and belief, and officially registered. ${ }^{37}$ In its recent decisions, the Constitutional Court has made it explicit that the validity of marriage may be determined only by its fulfilment of the requirements of religious laws (Paragraph 1).

34 Sebastiaan Pompe, "Mixed Marriages in Indonesia: Some Comments on the Law and the Literature," Bijdragen Tot de Taal-, Land-En Volkenkunde 144, no. 2/3 (1988): 270.

35 Article 4 stipulates that polygamy may only be exercised with the court's permission. Permission will be granted if a wife is unable to perform her duties as wife, suffers from physical defects or an incurable disease, and is incapable of having descendants. In Article 5, the requirements for polygamous marriage include: the approval of the wife or wives; the assurance that the husband will guarantee the necessities of life for his wives and their children; the guarantee that the husband shall act justly towards his wives and their children.

${ }^{36}$ Article 6 stipulates that marriage shall be founded upon agreement of the future spouses. A person who has not yet attained the age of 21 years shall obtain consent of their parent(s), guardian, or a family member. Article 7 sets the minimum age at 19 years for males and 16 years for females. The court may grant dispensation at the request of the parents.

37 See Mohd. Idris Ramulyo, Tinjauan Beberapa Pasal Undang-Undang Nomor 1 Tahun 1974 dari Segi Hukum Perkawinan Islam [Review of Some Articles of Law No. 1 of 1974 from the Perspective of Islamic Marriage Law] (Jakarta: IHC, 1986), 92-95; Ratno Lukito, Legal Pluralism in Indonesia: Bridging the Unbridgeable (London and New York: Routledge, 2013), 76. 
For the Court, registration does not determine the validity of a marriage, as it is simply an "administrative obligation required by the law". $3^{8}$

By employing the general wording of religion and beliefs, the Marriage Law seems to accommodate the plurality of religions and beliefs existing in Indonesia. With this multi-faith accommodation, it seems reasonable to anticipate the likelihood of marriages between persons of different religions and beliefs. Nonetheless, no clear provision is made to address the legality of such marriages. ${ }^{39}$ The withdrawal of draft Article 11, without an alternative provision, could only mean that interreligious marriages are not regulated. For many scholars, in the absence of such a provision, Article 66 would prevail. This article stipulates that in matters regulated by the Marriage Law, previous relevant laws, including the Dutch colonial era Regulation on Mixed Marriages (Regeling op de Gemengde Huwelijken, RGH), should be revoked. Since interreligious marriage is not regulated by the new law, the RGH would remain applicable..$^{40}$ Another scholar argues that Article 57, stipulating the rules for mixed marriages, regulated not only marriages between persons of different nationalities, but also interreligious marriages, and that the RGH would provide the binding rules of law in matters of interreligious marriages. ${ }^{41}$ Many other scholars reject the legal vacuum thesis. They suggest that interreligious marriage has already been regulated by Article 2(1). Some of them maintain that this article completely prohibits interreligious marriages, while others consider the validity of such marriages inconclusive, as some religions regard such marriages as legitimate. ${ }^{42}$

$3^{8}$ Judicial Review of Marriage Law, Decision of Constitutional Court No. 46/PUU-VIII/2010 (The Constitutional Court of the Republic of Indonesia, 2012).

39 Legal indeterminacies in the Marriage Law concerning Article 2(1) not only include the legal status of interreligious marriage, but also that of marriages between religious believers and adherents of local beliefs, and of marriages between atheists and believers. Marriages between atheists might not be protected under this law, unless the word 'beliefs' in the article is understood broadly to include all forms of belief, religious or otherwise.

40 Sudargo Gautama, "Mahkamah Agung dan Keanekaragaman Hukum Perdata [The Supreme Court and the Plurality of Private Law]," Hukum dan Pembangunan 17, no. 2 (1987): 163-69; J.C.T. Simorangkir, "Peranserta Gereja/Warga Gereja dalam Pembangunan dan Penegakan Hukum di Indonesia dalam Hukum [The Role of Church/Church Members in the Development and the Law Enforcement in Indonesia in the Law]," in Pelaksanaan Undang-Undang Perkawinan Dalam Perspektif Kristen [Implementation of the Marriage Law from the Christian Perspective], eds. Weinata Sairin and Joseph Marcus Pattiasina (Jakarta: PT BPK Gunung Mulia, 1994), 64-66; Pompe, "Mixed Marriages in Indonesia: Some Comments on the Law and the Literature."

${ }_{41}$ Ichtijanto, Perkawinan Campuran dalam Negara Republik Indonesia [Mixed Marriage in the Republic of Indonesia] (Jakarta: Badan Litbang Agama dan Diklat Keagamaan Departemen Agama RI, 2003).

42 The first view is widely held by many Muslim scholars and the Ministry of Religious Affairs. See Asmin, Status Perkawinan Antar Agama Ditinjau dari Undang-Undang Perkawinan No. 1/1974 [The Status of Interreligious Marriage According to the Marriage Law No. 1/1974] (Jakarta: PT Dian Rakyat, 1986), 68; Hilman Hadikusuma, Hukum Perkawinan Indonesia Menurut Perundangan, Hukum Adat, Hukum Agama [Marriage Law in Indonesia According 
With the promulgation of the Population Administration Law of 2006, the validity of interreligious marriage received statutory protection, although such a marriage must be approved, in advance, by a decree of the civil court. ${ }^{43}$ This legal arrangement seems to be distinctive, compared to those of secular states, which impose no restriction on interreligious marriage, and other countries with the personal status system, whereby Islamic family law is formally enforced. In most Muslim countries, interreligious marriage is permitted between a Muslim man and a non-Muslim woman who belongs to ahl al-kitāb (People of the Book, generally referring to adherents to Judaism and Christianity) but not otherwise. ${ }^{44}$ Although adopting the personal status system similar to that of Indonesia, Singapore and India have established civil marriage which would solemnize the marriages of different religions, including between Muslims and non-Muslims. ${ }^{45}$

Despite the fact that the current legal regime in Indonesia, particularly since the adoption of the Population Administration Law, does not prohibit interreligious marriage, there is no guarantee that all applications for this marriage will be registered. Recent studies have shown that some judges of civil courts will readily disapprove any application for the registration of an interreligious marriage. ${ }^{6}$ It is against this practical uncertainty, in addition to the aforementioned normative ambiguity, that a 2014 challenge to the Marriage Law, submitted to the Constitutional Court, is better understood.

to Legislation, Customary Law, Religious Law] (Bandung: Mandar Maju, 1990), 18-20. The second approach can be found in Rusli and R. Tama, Perkawinan Antar Agama dan Masalahnya sebagai Pelengkap UU Perkawinan No. 1 Th. 1974 [Interreligious Marriage and its Problem as an Addition to the Marriage Law No. 1 of 1974] (Bandung: Shantika Dharma, 1984).

43 Law No. 23 of 2006 on Population Administration, elucidation of Art. 35(a).

44 Jamal J.A. Nasir, The Status of Women under Islamic Law and Modern Islamic Legislation, 3rd ed. (Leiden and Boston: Brill, 2009), 85-86; Global Legal Research Directorate, Prohibition of Interfaith Marriage (The Law Library of Congress, 2015), https://www.loc.gov/law/help/marriage/prohibition-of-interfaith-marriage.pdf. Tunisia recently lifted the ban for interreligious marriage of a Muslim woman to a non-Muslim man. "Tunisia Lifts Ban on Muslim Women Marrying Non-Muslims," Aljazeera, September 14, 2017, https://www.aljazeera.com/news/2017/09/14/ tunisia-lifts-ban-on-muslim-women-marrying-non-muslims.

45 See Noor Aisha Abdul Rahman, "Muslim-Non-Muslim Marriage in Singapore," in Muslim-Non-Muslim Marriage: Political and Cultural Contestations in Southeast Asia, eds. Gavin W. Jones, Chee Heng Leng, and Maznah Mohamad (Singapore: ISEAS, 2009), 283-317; Yüksel Sezgin, Human Rights under State-Enforced Religious Family Laws in Israel, Egypt and India, Cambridge Studies in Law and Society (Cambridge: Cambridge University Press, 2013), chap. 6, https://doi.org/10.1017/CBO9781139649612.

46 See, for instance, Judith Koschorke, "Legal Pluralism in Indonesia: The Case of Interfaith Marriages Involving Muslims," in Legal Pluralism in Muslim Contexts, eds. Norbert Oberauer, Yvonne Prief, and Ulrike Qubaja (Leiden, The Netherlands: Brill, 2019), 213-14, https://doi.org/10.1163/9789004398269_010; Mohamad Abdun Nasir, "Religion, Law, and Identity: Contending Authorities on Interfaith Marriage in Lombok, Indonesia," Islam and Christian-Muslim Relations 31, No. 2 (April 2, 2020): 131-50, https://doi.org/10.1080/09596410.2020.1773618. 


\subsection{Applicant's Argument}

On 4 July 2014, Damian Agata Yuvens and others brought their application to the Constitutional Court to review the constitutionality of Article 2(1) of the Marriage Law. They argued that the Marriage Law, by confining the legitimacy of marriage to those taking place within, and as determined by, religions and beliefs recognized by the state, and by stipulating marriages performed outside those bounds as illegitimate, had coercively imposed the vision of the state regarding religion and belief. According to the applicants, the restrictive nature of the provision has forced some people to exploit legal loopholes use legal proceedings considered to be a form of legal fraud (fraus legis facta; penyelundupan hukum). The applicants applied for the conditional unconstitutionality of the impugned provision, so that the text of the article would read: "a marriage is legitimate, if it has been performed according to the laws of the respective religions and beliefs of the parties concerned, as long as their interpretation is assigned to each party." 47

The applicants proposed five arguments to support their application. First, the religious requirement for marriage validity contravened religious freedom as protected by the Constitution in Article $28 \mathrm{E}(1$ and 2$)$, Article 28I(1), and Article 29(2). They also argued that Article 2(1) of the Marriage Law had legitimized (impermissibly) the state as the true interpreter of religion in matters of marriage. In this way, the law was not consistent with the religious freedom enshrined in the Constitution, nor with the nature of the Pancasila state, as neither a secular nor a religious state. For the applicants, the state administration should not be part of the implementation of religion. Rather than it being a state matter, the solemnization of marriage should be at the behest of the persons willing to get married, in accordance with their conscience. The state duty regarding registration should not be conflated with religious interpretation and application. Viewed in this way, by the applicants, the state should not refuse to register marriage on the basis of religious considerations. ${ }^{48}$

Second, the restrictions on interreligious marriages, based on Article 2(1), violated the constitutional right to marry and to form a family, as

Judicial Review of Marriage Law, Decision of Constitutional Court No. 68/PUU-XII/2014 (The Constitutional Court of the Republic of Indonesia, 2015).

48 Judicial Review of Marriage Law, Decision No. 68, 16-21. 
enshrined in Article $28 \mathrm{~B}(1)$. By reference to international instruments such as the Universal Declaration of Human Rights and the International Covenant on Civil and Political Rights, the applicants pointed out that restrictions on marriage, on the basis of religion, were unacceptable. The national law of human rights should recognize religious restrictions on a marriage only to the extent which they were agreed to by the parties. By putting illegitimate restrictions on the rights of persons from different religions and beliefs to marry, the state violated its duty to protect the right of citizens to have legitimate marriages. To deny the legitimacy of interreligious marriages, according to the applicants, was to negate the legal consequences arising from such marriages, with regard to rights and responsibilities between spouses, and of children. Since interreligious marriage was unrecognized, children born from such marriage would remain socially stigmatized as being born out of wedlock. ${ }^{49}$

Third, according to the applicants, Article 2(1) enabled various interpretations, and this had resulted in conflicting norms, which failed to protect the constitutional right to the certainty of just laws (kepastian hukum yang adil) as established in Article $28 \mathrm{D}(1)$. The Constitution demands the protection of legal certainty, meaning that state laws should not be uncertain or ambiguous, in ways which would make them difficult to implement in practice, and should not create conflicting norms within the subject law, nor between this law and others. Article 2(1) could not provide such legal certainty. The article had given rise to a wide discretion in determining who had the authority to examine the conformity of marriage with religious requirements, and when a marriage could be considered valid. The validity of marriage could be determined by multiple, and possibly conflicting, interpretations, even within each religion or belief. ${ }^{50}$

Fourth, since Article 2(1) laid the basis for the state to discriminate against citizens of different religions, it violated the constitutional right to equality before the law, as guaranteed in Article 27(1) and Article $28 \mathrm{D}(1)$, and the right to freedom from discrimination, guaranteed in Article 28I(2). The impugned provision, which made different interpretations possible,

Judicial Review of Marriage Law, Decision No. 68, 22-25.

Judicial Review of Marriage Law, Decision No. 68, 26-35. The applicants made references to various interpretations within six recognized religions on the validity of interreligious marriage. 
has been interpreted differently by marriage registrants, so there has been different treatment for different citizens; in some cases, registrars registered interreligious marriages, while in others they refused to do so. ${ }^{51}$ Finally, the applicants argued that the limitation on rights provided by Article 2(1) was inconsistent with the provision of rights limitation, established in Article 28J(2) of the Constitution. The statutory limitation could be accepted in only two of four elements of the provision of rights limitation, ${ }^{52}$ since it was embodied in a legitimate law and implemented in a democratic society. The article therefore violated the rights and freedoms of others, and did not meet just requirements, based upon considerations of morality, religious values, security, and public order.

In addition to the above-mentioned substantive aspects of Article 2(1), which for the applicants were unconstitutional, they challenged the article in respect of its formal aspects. ${ }^{53}$ However, since the formal review argument was set aside by the Constitutional Court on the basis that the challenge was beyond the required time limit for a formal review, ${ }^{54}$ it is not discussed here.

\subsection{The Court's Decision}

The Constitutional Court rejected the application and argued for the constitutionality of the religious determination in Article 2(1) of the Marriage Law. In a brief, unelaborated decision, the Court argued that, despite the constitutional recognition of the right to marry and procreate, the Constitution allows limitations on the exercise of that right through legislation (Article 28J(2)). In addition, for the Court, religion is a basis of the state, and the state itself is responsible for safeguarding the fulfilment of the rights of citizens, with regard to marriage and family. Although there was no disagreement

51 Judicial Review of Marriage Law, Decision No. 68, 36-38.

52 According to the applicants, among the elements of the rights limitation stipulated in Article 28J(2) of the Constitution, only two elements, namely 'provided by law' and 'implemented in a democratic society', were satisfied by Article 2(1) of the Marriage Law.

53 The arguments of the applicants with regard to the formal aspects of the law include: implementation of the article has facilitated evasion of the law (fraus legis); the article did not satisfy the requirements of the legitimate rule of law; and implementation of the article on interreligious marriage was in contrast to its objective, as many persons willing to engage in interreligious marriage became apostates. Judicial Review of Marriage Law, Decision No. 68, 45-53. To support their application, the applicants submitted two experts and two witnesses. Judicial Review of Marriage Law, Decision No. 68, 60-72.

54 Judicial Review of Marriage Law, Decision No. 68, 150. Following its decision on the review of the Supreme Court Law of 2009, the Constitutional Court stated the maximum required time for formal review of a statute to be considered by the Court is 45 days since the statute's promulgation. See Judicial Review of Supreme Court Law, Decision of Constitutional Court No 27/PUU-VII/2009 (The Constitutional Court of the Republic of Indonesia , 2010). 
with respect to the judgment, Justice Maria Farida Indrati gave a separate argument in the form of a concurring opinion, which, putting aside her concluding judgment, in fact criticized the Marriage Law, particularly Article 2(1). Unlike the majority of the justices, Justice Indrati was concerned that the impugned provision had violated the rights of, particularly, those who would enter into interreligious marriages. Nonetheless, she rejected the application, for the reason that the conditional unconstitutionality the applicants proposed would give rise to legal uncertainty. 55

The decision of the Court demonstrates the significance of religion in matters of marriage. However, as is argued below, the Court failed adequately to engage the arguments of the applicants. There are at least four points of criticism of the decision. First, the reliance the Court placed on merely the first principle of Pancasila, in legitimating Article 2(1), would indicate its support for religious supremacy. Second, the Court did not consider how the right to marry of non-religionists and people of non-recognized religions was to be protected. Third, it failed to address the main concern of the application, namely the validity of interreligious or interfaith marriages, resulting in the enduring uncertainty of their validity. Finally, the reference to the limitation clause, particularly the religious values, to justify the religious determination, is likely unsupported by the terms of religion (Islam) itself.

\subsection{Analysis of the Court's Arguments}

\subsubsection{Religious Significance of Marriage}

The Court began its arguments for the religiosity of marriage by referring to the fourth paragraph of the Preamble, and Article 29(1) of the Constitution, in which the phrase 'belief in the One and Only God' is entrenched as the state ideology. As the Court pointed out, this reference suggested the constitutional acknowledgment of religion. As a consequence, the state acknowledges that the acts of citizens would be closely related to religion. ${ }^{56}$ In matters of marriage, religion was regarded to be the basis on which communities organize themselves, in relation to God, in order to implement God's will to maintain the continuity of the life of human

55 Judicial Review of Marriage Law, Decision No. 68, 155-62 [6.1-6.6].

${ }^{6}$ Judicial Review of Marriage Law, Decision No. 68, 151 [3.12.2]. 
beings. It was the duty of the state to guarantee the performance of this religion-related act. ${ }^{57}$

Throughout the arguments, the Court emphasized the religious character of marriage. Marriage was also viewed as a constitutional right, the fulfilment of which required respect to be given to the same right of others. The state, through its laws, protected yet regulated the exercise of this right, so that its application would not result in conflict between rights-holders..$^{8}$ For the Court, the Marriage Law "has realized the principles contained in Pancasila and the 1945 Constitution and has accommodated all existing social facts". 59 Hence, in considering the nature of legitimate marriage, the Court would follow the marriage stipulations in this law. For instance, marriage was described as a relationship of body and soul, containing formal, social and spiritual aspects, which was founded on the belief in the One and Only God'. The Court also agreed that the validity of marriage is determined by religion, and that the role of the state is to guarantee its administrative legality.

The Court rejected the applicants' argument that the religious determination of marriage validity required the state to compel people to follow their respective religious laws. For the Court, since marriage has been regulated by legislation, what people have to do is to be "obedient and submissive, and not in conflict with, or in violation of, legislation”.60 This seemed to mean that what people are bound to follow is in fact state law, not religion per se. However, as the law legitimizes adherence to the dictates of religion or belief, in matters of marriage, the response of the Court became a mere circular argument.

The Court's arguments raise some critical issues. To associate the Pancasila state ideology with only its first principle of belief in the One and Only God' is undoubtedly erroneous, except if it is meant as being a part of the ideology. This first principle was relied upon by the Court to justify the religiosity of marriage. This raises a foundational problem of marriage: why this single principle, excluding all others, provides the basis for justifying

Judicial Review of Marriage Law, Decision No. 68, 153 [3.12.5].

Judicial Review of Marriage Law, Decision No. 68, 151 [3.12.2].

59 Judicial Review of Marriage Law, Decision No. 68, 152 [3.12.3]. This statement is similar to that found in the Marriage Law. See Law No. 1 of 1974 on Marriage, General Elucidation, para. 3.

6o Judicial Review of Marriage Law, Decision No. 68, 152 [3.12.4]. 
marriage. Marriage might also be approached from the point of Pancasila's second principle, 'just and civilized humanity', meaning that marriage is part of human rights and collective human expression. Marriage, as a human right, has been recognized internationally ${ }^{61}$ and adopted by the Indonesian Constitution and the Human Rights Law. ${ }^{62}$ The reference to only the first principle indicates judicial support of religious supremacy, an approach of strong religious constitutionalism.

On the basis of the first principle, the Court has restricted the scope of marriage to what is permitted by religion; there would be no valid marriage outside the bounds of religion. Nonetheless, the principle "belief in the One and Only God' does not aspire to strong religiosity. If that were the case, all areas of life, public and private, would be regulated on the basis of religion. This principle, accordingly, should not be interpreted to invalidate all nonreligious marriages. As is also argued below, the restriction on non-religious marriages would be unjustifiable, by the authority of religion itself.

The reliance the Court placed on religion brings up some critical points. First, the Court did not give a definition or criteria of what religion is, for the purpose of the validity of any marriage. Unlike its decisions in the Blasphemy Law Case ${ }^{63}$ and the Local Beliefs Case, ${ }^{64}$ the Court failed to address whether the word 'religion' should be inclusive. If the Court defers to the Marriage Law, and the existing practices of legitimate marriage, it would most likely cause a very restrictive concept of religion, to the effect that marriage would be valid only if it were conducted according to the practices of recognized religions. ${ }^{65}$ The fact that the Court did not elaborate further on the use of religion and its signification seems to suggest this deference. If this is the case, the rights of believers of non-recognized religions, let alone those of non-believers, would be denied. In addition to violating the right to marry,

61 "Universal Declaration of Human Rights" (GA Res. 217A (III), UN GAOR, UN Doc. A/810 (10 December 1948), Art. 16; "International Covenant on Civil and Political Rights" (opened for signature 19 December 1966, 999 UNTS 171 (entered into force 23 March 1976), Art. 23.

62 Constitution of the Republic of Indonesia 1945, Art. 28B(1); Law No. 39 of 1999 on Human Rights, Art. 10.

63 Judicial Review of Blasphemy Law, Decision of Constitutional Court No 140/PUU-VII/2009 (The Constitutional Court of the Republic of Indonesia, 2010).

64 Judicial Review of Population Administration Law, Decision of Constitutional Court No 97/PUU-XIV/2016 (The Constitutional Court of the Republic of Indonesia, 2017).

65 As mentioned in the application, the religious organizations giving their submissions to the case represented six recognized religions. There was no representative from non-recognized religions or local beliefs appearing before the court. 
such a restriction would be contrary to the constitutional right to nondiscrimination, as provided by Article 28I(2).

Second, the Court's overemphasis on the role of religion in marriage not only delegitimizes non-religious marriage, but also undermines local beliefs-based marriage. By limiting marriage to religious marriage, the Court seemed to be suggesting that everyone, even a non-religious person, has to marry according to a religion. Here, like the first concern, Article 2(1) would severely limit religious freedom. In addition, despite its mention of belief (kepercayaan) together with religion, similar to the text of the Marriage Law (Article 2(1)), the Court refers to religion only, as a determinant of marriage validity, while ignoring local beliefs. It is not clear whether, for the Court, religion in marriage includes local beliefs.

Third, even though the Court dealt with the constitutionality of Article 2(1), it did not mention, let alone engage with, the main concern of the application and all the submissions, namely the validity of interreligious or interfaith marriages. By being silent on this matter, the Court seemed to maintain the existing ambiguity of the legal status of interreligious marriage, leaving it to the government to regulate, and consequently making it vulnerable to various restrictions or to being uncertain of protection. Although the Population Administration Law has facilitated the legalization of interreligious marriage applications, as discussed earlier, ordinary courts do not always grant approval. Some judges refuse to approve such marriages, because they take the view that Article 2(1) renders them illegitimate. ${ }^{66}$ Here, the religious determination is understood as requiring the embrace of the same religion, of persons willing to marry, and, as such, prohibiting interreligious marriage to be conducted and registered. Even the Supreme Court in its recent decision easily dismissed an inter-religion marriage application on the basis of this provision, without considering its established precedent in the 1989 decision and the Population Registration Law. ${ }^{67}$ In

66 For instance, Decree of District Court of Ungaran No. 08/Pdt.P/2013/PN.Ung (The Supreme Court of the Republic of Indonesia, 2013); Decree of District Court of Blora No 71/Pdt.P/2017/PN Bla (The Supreme Court of the Republic of Indonesia, 2017).

67 Supreme Court Decree No. 1977 K/Pdt/2017 (The Supreme Court of the Republic of Indonesia, 2017). Irrespective of this decision, many civil courts still give their approval for interreligious marriage applications. See, for instance, Decree of District Court of Surakarta No. 186/Pdt.P/2018/PN.Skt (The Supreme Court of the Republic of Indonesia, 2018); Decree of District Court of South Jakarta No. 1139/Pdt.P/2018/PN.Jkt.Sel (The Supreme Court of the Republic of Indonesia, 2019). 
addition, in 2019, in compliance with a legal opinion (fatwa) of the Supreme Court, the General Director of the Population and Civil Registration of the Ministry of Home Affairs issued a circular addressed to all civil registries, directing them to dismiss any interreligious marriage application, because such marriages were unlawful. ${ }^{68}$

Fourth, the claim the Court made, regarding the completeness or otherwise of the Marriage Law, is contrary to the unresolved problem of interreligious marriage legitimacy, which has been debated since the promulgation of the Marriage Law. Such a claim not only ignores this enduring problem, granting no express protection of the right to marry a person of a different religion/ faith, but also fails to acknowledge the weaknesses inherent in some of the provisions of the Marriage Law, as the Court itself has noted in some of its previous decisions. The Court, in some cases, has invalidated or made amendments to some provisions in the Marriage Law by using conditional unconstitutionality, such as in the Illegitimate Children Case, in which the Court held that Article 43(1) of the Marriage Law, which provided that a child born out of wedlock only has a civil relationship with his/her mother or the family of mother, was unconstitutional, unless it was interpreted as including the relationship of the child with his/her father and the family of his/her father, as can be proven by science and technology, or other legal evidence. ${ }^{69}$ The Marriage Agreement Case ${ }^{70}$ is also evidence of the Court's criticism of the Marriage Law. In this later case, the Court held that the provisions in Article 29 of the Marriage Law, concerning an unchangeable prenuptial agreement, were conditionally unconstitutional, so that the article should now be read as allowing modification of this agreement, during marriage.

\subsubsection{Religious Marriage and Rights Limitation}

In response to the arguments of the applicants regarding the limitation of rights created by the impugned provision of the Marriage Law, the Court limited itself to two issues of limitation, while other remaining issues were

68 Letter of Director General of Population and Civil Registry No. 472.2/3315/DUKCAPIL on Explanation in Matters of Civil Registry, 2019.

69 Judicial Review of Marriage Law, Decision of Constitutional Court No. 46/PUU-VIII/2010 (The Constitutional Court of the Republic of Indonesia, 2012).

70 Judicial Review of Marriage Law, Decision of Constitutional Court No. 69/PUU-XIII/2015 (The Constitutional Court of the Republic of Indonesia, 2016). 
set aside without explanation. The two issues addressed were the limitations on the right to marry, and those on the right to religious freedom. Firstly, against the argument of the applicants that Article 2(1) restricted their right to establish a family through a legitimate marriage, in accordance with Article $28 \mathrm{~B}(1)$ of the Constitution, the Court referred to the limitation clause (Article 28J(2)), to the effect that the limitation created by the impugned article was justified, as it was provided by a statute, made to protect rights and freedoms of others, and was consistent with considerations based on morality, religious values, safety and public order. ${ }^{71}$ How these considerations could justify this limitation, however, was not further elaborated. The fact that the limitation was provided in a statute (the Marriage Law) seemed, for the Court, to be a sufficient ground for the legitimacy of the limitation.

The second issue of limitation concerned religious freedom. The Court rejected the argument that the impugned provision permitted the state to engage in undue interference with religion and belief, by dictating its own interpretation of religion and belief. Against this claim, the Court emphasized the complementary relation between religion and state, in matters of marriage, in that religion provided the basis for human activities in establishing a family through God-sanctioned marriage, while the state guaranteed their legal certainty and protection. ${ }^{2}$ This, however, did not answer the concerns with the state's religious interference.

The state's recognition and regulation of religious marriage is arguably not inconsistent with freedom of religion. ${ }^{73}$ What would raise a question of consistency is when religious marriage is the only form of marriage which the state recognizes. The state, in regulating religious marriage, unavoidably makes its own interpretation of what a valid marriage is, according to religion. In the case of different religious interpretations, considered to be legitimate in religious communities, the state would likely choose, from

71 Judicial Review of Marriage Law, Decision of Constitutional Court No. 68/PUU-XII/2014 (The Constitutional Court of the Republic of Indonesia, 2015), 151 [3.12.3].

72 Judicial Review of Marriage Law, Decision No. 68, 152-3 [3.12.5].

73 On justification of religious marriage, see Ayelet Shachar, "Faith in Law? Diffusing Tensions Between Diversity and Equality," in Marriage and Divorce in a Multicultural Context: Multi-Tiered Marriage and the Boundaries of Civil Law and Religion, ed. Joel A. Nichols (Cambridge: Cambridge University Press, 2012), 341; Gideon Sapir and Daniel Statman, "Religious Marriage in a Liberal State," in Constitutional Secularism in an Age of Religious Revival, eds. Susanna Mancini and Michel Rosenfeld (Oxford: Oxford University Press, 2014), 269-82, https:// doi.org/10.1093/acprof:0so/9780199660384.003.0015. 
various religious interpretations, one which is considered representative of all, or suitable for meeting state policies. This is precisely what has been achieved by the regulations of Islamic marriage, and its bureaucratization, through the Ministry of Religious Affairs. In this sense, the claim, that the state would dictate its own religious interpretation, seems to be justified. The state acts not only as a protector and guarantor of religious marriage, but also as the ultimate determinant of its legitimacy. On the other hand, this religious marriage exclusivism either deprives non-religious believers of their right to marriage, or requires them to perform religious marriages, against their consciences. Accordingly, to be consistent with the concept of religious freedom, the policy of religious marriage needs to be relaxed. As the United Nations Human Rights Committee, in its General Comment No. 19, on the Family, has stated: "the right to freedom of thought, conscience and religion implies that the legislation of each State should provide for the possibility of both religious and civil marriages."74 The Indonesian legal realities have in fact caused some relaxations to be made to religious marriage exclusivism, through the registration of marriages between persons of local beliefs, ${ }^{75} \mathrm{a}$ fact that the Constitutional Court in this case failed to acknowledge.

In the two arguments mentioned above, the Court gave emphasis to the role of religion in the limitation of rights. Although it is not the sole consideration for the limitation of the right to marry, the consideration of 'religious values' is likely, in an examination of the whole of the arguments the Court has made, to constitute the most important point of reference. However, the Court did not elaborate on what religious values, in matters of marriage, should look like. It also did not fairly appeal to religious reasoning, in arguing for the constitutionality of the impugned law. The Court seemed to assume that marriage was embedded in every religion, and that all religions would likely be in agreement on this matter.

In other cases concerning the constitutionality of some provisions of the Marriage Law, the Court employed religious reasoning, either limited to Islamic legal arguments, or in comparative religious perspectives. The use

74 Human Rights Committee, "General Comment No. 19: Article 23 (The Family) Protection of the Family, the Right to Marriage and Equality of the Spouses" (39th Sess., UN Doc. CCPR/C/21/Rev.1/Add.2 (27 July 1990), para. 4.

75 Law No. 23 of 2006 on Population Administration. 
of exclusively Islamic reasoning is evident in the Polygamy Case. ${ }^{76}$ Despite the fact that the Marriage Law regulates polygamy in general, encompassing any person whose religion or belief allows polygamous marriage, the Court limited its legal reasoning to Islamic law, relying on the Qur'an and Muslim juristic interpretation. ${ }^{77}$ On the other hand, in the Marriageable Age Case 1, the Court used comparative religious arguments in its holding for the constitutionality of the provision of marriageable age (Article $7^{(1)}$ of the Marriage Law). In its argument that the minimum age for marriage is indeterminate, and as such open to different settlements, the Court referred to principles and provisions in Islamic law and Hinduism..$^{78}$ These religious approaches are different from the other, purely secular, approach the Court took, for example, in reviewing the constitutionality of the Marriage Law's provision on illegitimate children, as outlined in Article 43(1). In this latter case, ${ }^{79}$ the Court merely referred to the argument of correctness and fairness, conditionally to invalidate the impugned provision.

The case under discussion, similarly to the former, religious approach made, demonstrates that the religious consideration could be acceptable in a constitutional argument. The main problem is how such consideration remains consistent with constitutionalism. In the matter of marriage validity, the Court has so far accepted, exclusively, the religious determination. Nevertheless, the question is whether religion itself necessitates the fulfilment of religious requirements, for a marriage to be religiously legitimate. The fact is that this is not the case. In Islam, for instance, the majority of Muslim jurists do not require such religiously sanctioned marriage to be valid according to Islamic law. A marriage conducted among non-Muslims, either People of the Book (Ahl al-Kitāb) ${ }^{80}$ including Jews and Christians, or among pagans/

76 Judicial Review of Marriage Law, Decision of Constitutional Court No. 12/PUU-V/2007 (The Constitutional Court of the Republic of Indonesia, 2007). In this case, the impugned provisions are Articles 3(1)(2), 4(1)(2), 5(1), 9, 15, and 24 of the Marriage Law, all of which regulate the requirements for polygamous marriage.

77 Judicial Review of Marriage Law, Decision No. 12, 91-6 [3.15]. The Court referred to two chapters of the Qur'an: al-Rūm: 21 and al-Nisā': 1, 3, 129, and to the religious views of M. Quraish Shihab, a professor in Qur'anic sciences at State Islamic University, Jakarta. On this case, see Simon Butt, "Islam, the State and the Constitutional Court in Indonesia," Pacific Rim Law \& Policy Journal 19 (2010): 287-96.

78 Judicial Review of Marriage Law, Decision of Constitutional Court No. 30-74/PUU-XII/2014 (The Constitutional Court of the Republic of Indonesia, 2015).

79 Judicial Review of Marriage Law, Decision of Constitutional Court No. 46/PUU-VIII/2010 (The Constitutional Court of the Republic of Indonesia, 2012). In this case, in addition to the provision on illegitimate children, the application reviewed the provision on marriage registration (Article 2(2)).

8o The term 'Ahl al-Kitāb' (People of the Book) traditionally refers to Jews and Christians. Early Muslim authorities included Sabeans (șābi'ah) and Magians/Zoroastrians (majūs). Abū al-Ḥasan 'Alī ibn Muhammad ibn Habīb al- 
polytheists (mushrikūn), or even non-religionists, can be justified, and so its validity will be maintained if they convert to Islam. ${ }^{81}$ The limitation on the right to marry, on the basis of religion, is therefore not supported by religious law itself, at least as interpreted by the majority of Muslims jurists.

Likewise, the consideration of religious values which restricts marriage between persons of different religions, might not be justified by religion itself. Religious views on the validity of interreligious marriage vary, as evident from the statements submitted by religious organizations during the proceedings of the case. More than that, within one religious tradition itself there exists a multiplicity of views. In Islamic law, for instance, the validity of interreligious marriages has been disputed ever since the early period of Islam. The majority of Muslim jurists since the classical period, and the legal practice in modern Islamic countries, as mentioned earlier, ${ }^{82}$ legitimize marriages between Muslim men and non-Muslim women of Ahl al-Kitāb. There is only a minority view, associated with 'Abd Allāh ibn 'Umar (d 693 CE), a companion of the Prophet, and some scholars of the Imàmiyyah (Twelver Shia), which prohibits Muslims from marrying non-Muslims, either men or women. ${ }^{83}$ This minority view, albeit with different reasons, is in fact the basis of fatwa, against interreligious marriage, issued by many Islamic organizations in Indonesia, such as Nahdlatul Ulama, Muhammadiyah and the Indonesian Ulema Council (MUI). ${ }^{84}$ In a fatwa issued in 2005, the MUI

Māwardī, Al-Hāwī al-Kabìr fĩ Fiqh al-Imām al-Shāfi'i [The Large Container in the Jurisprudence of Imam Shafi'i], vol. 9 (Beirut: Dār al-Kutub al-'Ilmiyyah, 1994), 223-26; Muwaffaq al-Dīn Abū Muḥammad 'Abd Allāh ibn Aḥmad ibn Muḥammad Ibn Qudāmah, Al-Mugnī [The Enricher], vol. 7 (Beirut: Dār al-Kitāb al-'Arabī, 1983), 501-3. In later periods, some Muslim scholars included Hindus, Buddhists and Confucians. Muḥammad Rashīd Rị̣ā, Tafsīr al-Qur'ān al-Hakìm (Tafsīr al-Mannār) [Commentary on al-Qur'an (al-Mannār Commentary)], vol. 6 (Cairo: Dār al-Mannār, 1947), 187-90.

${ }_{81}$ On the opinions of Muslim jurists on the validity of non-Islamic marriages, see Ibn Qudāmah, Al-Mugnī, 7:531; Ibn al-Humām Kamāl al-Dīn Muḥammad ibn 'Abd al-Wāḥid, Sharh Fath al-Qadìr [Commentary on Fath al-Qadirr], vol. 3 (Beirut: Dār al-Kutub al-'Ilmiyyah, 2003), 390-93; 'Abd al-Karīm Zaydān, Aḥām al-Żimmiyyīn wa al-Musta'minīn fi Dār al-Islām [Laws on Non-Muslims and Asylum-Seekers in the Muslim Territory] (Beirut: Mu'assasah al-Risālah and Maktabah al-Quds, 1982), 356-67.

82 See note 31 above.

83 al-Māwardī, Al-Ḥāwī al-Kabīr fī Fiqh al-Imām al-Shāfi'ī, 9:221-22; Abū al-Walīd Ibn Rushd, Bidāyah al-Mujtahid wa Nihāyah al-Muqtașid [The Beginning for the One Who Exercises Independent Reasoning and the End for the One Who Would Limit Himself], 6th ed., vol. 2 (Beirut: Dār al-Ma'rifah, 1982), 44. On different views amongst Twelver Shia scholars regarding marriage of Muslim men to women of Ahl al-Kitāb, see Muhammad Jawād Mughniyyah, Al-Fiqh 'alā al-Mażāhib al-Khamsah [Islamic Law According to Five Schools of Law], 1oth ed., vol. 2 (Beirut: Dār al-Tayyār al-Jadīd, 2008), 48-49.

84 Muhamad Ali, "Fatwas on Inter-Faith Marriage in Indonesia," Studia Islamika: Indonesian Journal for Islamic Studies 9, No. 3 (2002): 1-33; Suhadi Cholil, "The Politico-Religious Contestation: Hardening of the Islamic Law on Muslim-Non-Muslim Marriage in Indonesia," in Muslim-Non-Muslim Marriage: Political and Cultural Contestations in Southeast Asia, eds. Gavin W. Jones, Chee Heng Leng, and Maznah Mohamad (Singapore: ISEAS, 2009), $139-58$. 
held that interreligious marriage, including a marriage between Muslim men and women from Ahl al-Kitāb, is "harām [prohibited] and unlawful".85 With regard to marriage between Muslim women and non-Muslim men, despite the assumed consensus of Muslim jurists in the past on its prohibition, ${ }^{86}$ the validity of this marriage is currently contested by some scholars, arguing that the reasons for the prohibition no longer prevail. ${ }^{87}$

The legal pluralism within Islamic law makes the argument for outlawing interreligious marriages, on the basis of the religious values consideration, tenuous. This is in addition to the plurality of views within religious traditions other than Islam, in Indonesia, of the status of interreligious marriage, many of which consider such marriage legitimate. ${ }^{88}$ Instead of limiting interreligious marriage, religious consideration could therefore provide justification for its validity. This stance would be principally consistent with the constitutional principles of human rights, particularly the rights to marriage and religious freedom, and with the fact that there are no legitimate grounds for rights limitations, in accordance with Article 28J(2).

\section{CONCLUSION}

This paper has demonstrated how Article 29(1) was made and understood by both the makers of the original Constitution and by the drafters of the amended Constitution. As has been argued, the phrase 'belief in the One and Only God' is a general reference to religion. This would mean that Article 29(1) concerns all religions, without any implied exclusion of non-monotheistic religions. This article affirms what is called the middle way of state-religion relations, encapsulated in the Pancasila state, which is located between an exclusively secular state and a religious or theocratic state. This means the Pancasila state does not endorse the supremacy of religion (and religious law) found in religious constitutionalism. In such a state, there should be no official

\footnotetext{
85 Fatwa of the Indonesian Ulema Council No. 4/MUNAS VII/MUI/8/2005 on Interreligious Marriages (28 July 2005 ).

86 Many classical Muslim jurists discussed the legitimacy and preservation of the marriage of a woman converting to Islam to a non-Muslim man. See Yohanan Friedmann, Tolerance and Coercion in Islam: Interfaith Relations in the Muslim Tradition (Cambridge: Cambridge University Press, 2003), 161-70.

87 Kecia Ali, Sexual Ethics and Islam: Feminist Reflections on Qur'an, Hadith, and Jurisprudence (Oxford: Oneworld, 2006), 14-21; Siti Musdah Mulia, "Promoting Gender Equity Through Interreligious Marriage: Empowering Indonesian Women," in Muslim-Non-Muslim Marriage: Political and Cultural Contestations in Southeast Asia, eds. Gavin W. Jones, Chee Heng Leng, and Maznah Mohamad (Singapore: ISEAS, 2009), 255-82.

88 This is demonstrated in various submissions to the case from religious organizations.
} 
religion(s). Restricting the definition of religion to only a few state-recognized religions would therefore be constitutionally unjustified.

The Constitutional Court, as the constitutionally most authoritative interpreter of the Constitution, has referred to the phrase 'belief in the One and Only God' in some of its decisions. In the Interreligious Marriage Case, the Court held the constitutionality of the provision of religious marriage exclusivism. The majority of the justices in this case relied on the belief in the supremacy of religion in matters of marriage. No attempts were made to balance the principle of 'belief in the One and Only God' with other fundamental values and principles of the Constitution. As a consequence, no consideration was given to the right to marry of non-religionists and people of non-recognized religions. It has also been argued that even if religion, Islam in particular, is employed in the Court's reasoning, the result would be consistent with the principle of human rights protection in the Constitution.

The Court's interpretation of Article 29(1) in the Interreligious Marriage Case has brought strongly religious overtones to the Constitution. Its arguments would lead to the adoption of the supremacy of religion, contrary to what the makers and drafters of the Constitution intended. The case underlies a tension in Indonesian constitutionalism, between the Constitution as it ought to be understood and its interpretation.

\section{BIBLIOGRAPHY}

Abdul Rahman, Noor Aisha. "Muslim-Non-Muslim Marriage in Singapore." In Muslim-Non-Muslim Marriage: Political and Cultural Contestations in Southeast Asia, edited by Gavin W. Jones, Chee Heng Leng, and Maznah Mohamad. Singapore: ISEAS, 2009.

Ahdar, Rex and Ian Leigh. Religious Freedom in the Liberal State. 2nd ed. Oxford: Oxford University Press, 2013.

Ali, Kecia. Sexual Ethics and Islam: Feminist Reflections on Qur'an, Hadith, and Jurisprudence. Oxford: Oneworld, 2006.

Ali, Muhamad. "Fatwas on Inter-Faith Marriage in Indonesia." Studia Islamika: Indonesian Journal for Islamic Studies 9, no. 3 (2002). 
Asmin. Status Perkawinan antar Agama Ditinjau dari Undang-Undang Perkawinan No. 1/1974 [The Status of Interreligious Marriage According to the Marriage Law No. 1/1974]. Jakarta: PT Dian Rakyat, 1986.

Backer, Larry Catá. "Theocratic Constitutionalism: An Introduction to a New Global Legal Ordering." Indiana Journal of Global Legal Studies 16 (2009).

Basalim, Umar. Pro-Kontra Piagam Jakarta di Era Reformasi [Pros and Cons of the Jakarta Charter in the Reform Era]. Jakarta: Pustaka Indonesia Satu, 2002. Butt, Simon. "Islam, the State and the Constitutional Court in Indonesia." Pacific Rim Law \& Policy Journal 19 (2010).

Cholil, Suhadi. "The Politico-Religious Contestation: Hardening of the Islamic Law on Muslim-Non-Muslim Marriage in Indonesia." In Muslim-Non-Muslim Marriage: Political and Cultural Contestations in Southeast Asia, edited by Gavin W. Jones, Chee Heng Leng, and Maznah Mohamad. Singapore: ISEAS, 2009.

\section{Constitution of France}

Constitution of the Islamic Republic of Afghanistan.

Constitution of the Islamic Republic of Iran.

Constitution of the Republic of Indonesia 1945.

Constitution of the Republic of Turkey.

Darmaputera, Eka. Pancasila and the Search for Identity and Modernity in Indonesian Society: A Cultural and Ethical Analysis. Leiden: E. J. Brill, 1988.

Decree of District Court of Blora No. 71/Pdt.P/2017/PN Bla (The Supreme Court of the Republic of Indonesia, 2017).

Decree of District Court of South Jakarta No. 1139/Pdt.P/2018/PN.Jkt.Sel (The Supreme Court of the Republic of Indonesia, 2019).

Decree of District Court of Surakarta No. 186/Pdt.P/2018/PN.Skt (The Supreme Court of the Republic of Indonesia, 2018).

Decree of District Court of Ungaran No. 08/Pdt.P/2013/PN.Ung (The Supreme Court of the Republic of Indonesia, 2013).

Dustūr Jumhūriyyah Mișr al-'Arabiyyah [Constitution of the Arab Republic of Egypt]. 
Elson, R.E. "Two Failed Attempts to Islamize the Indonesian Constitution." SOJOURN: Journal of Social Issues in Southeast Asia 28, no. 3 (November 2013).

Indonesian Ulema Council Fatwa No. 4/MUNAS VII/MUI/8/2005 on Interreligious Marriages (28 July 2005).

Friedmann, Yohanan. Tolerance and Coercion in Islam: Interfaith Relations in the Muslim Tradition. Cambridge: Cambridge University Press, 2003.

Gautama, Sudargo. "Mahkamah Agung dan Keanekaragaman Hukum Perdata [The Supreme Court and the Plurality of Private Law]." Hukum dan Pembangunan 17, No. 2 (1987).

Global Legal Research Directorate. Prohibition of Interfaith Marriage. The Law Library of Congress, 2015. https://www.loc.gov/law/help/marriage/ prohibition-of-interfaith-marriage.pdf.

Hadikusuma, Hilman. Hukum Perkawinan Indonesia Menurut Perundangan, Hukum Adat, Hukum Agama [Marriage Law in Indonesia According to Legislation, Customary Law, Religious Law]. Bandung: Mandar Maju, 1990. Hazairin. Demokrasi Pantjasila [Pancasila Democracy]. Jakarta: Tintamas, 1970. Hirschl, Ran. Constitutional Theocracy. London: Harvard University Press, 2010. Hosen, Nadirsyah. Sharia and Constitutional Reform in Indonesia. Singapore: ISEAS, 2007.

Human Rights Committee. "General Comment No. 19: Article 23 (The Family) Protection of the Family, the Right to Marriage and Equality of the Spouses." 39th Sess., UN Doc. CCPR/C/21/Rev.1/Add.2 (27 July 1990).

Ibn Qudāmah, Muwaffaq al-Dīn Abū Muḥammad 'Abd Allāh ibn Aḥmad ibn Mụ̣ ammad. Al-Mugnī [The Enricher]. Vol. 7. Beirut: Dār al-Kitāb al-'Arabī, 1983.

Ibn Rushd, Abū al-Walīd. Bidāyah Al-Mujtahid Wa Nihāyah al-Muqtașid [The Beginning for the One Who Exercises Independent Reasoning and the End for the One Who Would Limit Himself]. 6th ed. Vol. 2. 2 vols. Beirut: Dār al-Ma'rifah, 1982.

Ichtijanto. Perkawinan Campuran dalam Negara Republik Indonesia [Mixed Marriage in the Republic of Indonesia]. Jakarta: Badan Litbang Agama dan Diklat Keagamaan Departemen Agama RI, 2003. 
"International Covenant on Civil and Political Rights." Opened for signature 19 December 1966, 999 UNTS 171 (entered into force 23 March 1976).

Judicial Review of Blasphemy Law, Decision of Constitutional Court No. 140/ PUU-VII/2009 (The Constitutional Court of the Republic of Indonesia, 2010). Judicial Review of Criminal Law, Decision of Constitutional Court No. 46/PUUXIV/2016 (The Constitutional Court of the Republic of Indonesia, 2017). Judicial Review of Marriage Law, Decision of Constitutional Court No. 12/ PUU-V/2007 (The Constitutional Court of the Republic of Indonesia, 2007). Judicial Review of Marriage Law, Decision of Constitutional Court No. 30-74/ PUU-XII/2014 (The Constitutional Court of the Republic of Indonesia, 2015). Judicial Review of Marriage Law, Decision of Constitutional Court No. 46/PUUVIII/2010 (The Constitutional Court of the Republic of Indonesia, 2012). Judicial Review of Marriage Law, Decision of Constitutional Court No. 68/PUUXII/2014 (The Constitutional Court of the Republic of Indonesia, 2015). Judicial Review of Marriage Law, Decision of Constitutional Court No. 69/PUUXIII/2015 (The Constitutional Court of the Republic of Indonesia, 2016). Judicial Review of Population Administration Law, Decision of Constitutional Court No. 97/PUU-XIV/2016 (The Constitutional Court of the Republic of Indonesia, 2017).

Judicial Review of Supreme Court Law, Decision of Constitutional Court No. 27/ PUU-VII/2009 (The Constitutional Court of the Republic of Indonesia, 2010). Kamāl al-Dīn Muḥammad ibn 'Abd al-Wāḥid, Ibn al-Humām. Sharḥ Fatḥ al-Qadīr [Commentary on Fath al-Qadīr] 3. Beirut: Dār al-Kutub al-'Ilmiyyah, 2003. Koschorke, Judith. "Legal Pluralism in Indonesia: The Case of Interfaith Marriages Involving Muslims." In Legal Pluralism in Muslim Contexts, edited by Norbert Oberauer, Yvonne Prief, and Ulrike Qubaja, 199-229. Leiden, The Netherlands: Brill, 2019. https://doi.org/10.1163/9789004398269_o10.

Kuru, Ahmet T. Secularism and State Policies toward Religion: The United States, France and Turkey. New York: Cambridge University Press, 2009.

Kusuma, A. B., ed. Lahirnya Undang-Undang Dasar 1945: Memuat Salinan Dokumen Otentik Badan Oentoek Menyelidiki Oesahaz Persiapan Kemerdekaan [The Birth of the 1945 Constitution: Containing Copies of Authentic Documents of 
the Investigating Committee for the Preparation for Indonesian Independence]. Revised. Jakarta: Badan Penerbit Fakultas Hukum Universitas Indonesia, 2009. Law No. 1 of 1974 on Marriage.

Law No. 23 of 2006 on Population Administration.

Law No. 39 of 1999 on Human Rights.

Letter of Director General of Population and Civil Registry No. 472.2/3315/ DUKCAPIL on Explanation in Matters of Civil Registry, 2019.

Lukito, Ratno. Legal Pluralism in Indonesia: Bridging the Unbridgeable. London and New York: Routledge, 2013.

Majelis Permusyawaratan Rakyat Republik Indonesia [People's Consultative Assembly]. Risalah Perubahan Undang-Undang Dasar Negara Republik Indonesia Tahun 1945: Tahun Sidang 2000, Buku Lima [Minutes of the Amendment of the 1945 Constitution of the Republic of Indonesia: Meeting Year 200o, Book Five]. Revised. Jakarta: Sekretariat Jenderal, 2010.

Majelis Permusyawaratan Rakyat Republik Indonesia [People's Consultative Assembly]. Risalah Perubahan Undang-Undang Dasar Negara Republik Indonesia Tahun 1945: Tahun Sidang 2000, Buku Satu [Minutes of the Amendment of the 1945 Constitution of the Republic of Indonesia: Meeting Year 2000, Book One]. Revised. Jakarta: Sekretariat Jenderal, 2010.

Majelis Permusyawaratan Rakyat Republik Indonesia [People's Consultative Assembly]. Risalah Perubahan Undang-Undang Dasar Negara Republik Indonesia Tahun 1945: Tahun Sidang 200o, Buku Tujuh [Minutes of the Amendment of the 1945 Constitution of the Republic of Indonesia: Meeting Year 200o, Book Seven]. Revised. Jakarta: Sekretariat Jenderal, 2010.

Majelis Permusyawaratan Rakyat Republik Indonesia [People's Consultative Assembly]. Risalah Perubahan Undang-Undang Dasar Negara Republik Indonesia Tahun 1945: Tahun Sidang 2002, Buku Lima [Minutes of the Amendment of the 1945 Constitution of the Republic of Indonesia: Meeting Year 2002, Book Five]. Revised. Jakarta: Sekretariat Jenderal, 2010.

Māwardī, Abū al-Hasan 'Alī ibn Muḥammad ibn Habīb al-. Al-Hāwī al-Kabīr fì Fiqh al-Imām al-Shāfi' [The Large Container in the Jurisprudence of Imam Shafi'i]. Vol. 9. 18 vols. Beirut: Dār al-Kutub al-'Ilmiyyah, 1994. 
Mughniyyah, Muḥammad Jawād. Al-Fiqh 'alā al-Mażāhib al-Khamsah [Islamic Law According to Five Schools of Law]. 1oth ed. Vol. 2. 2 vols. Beirut: Dār al-Tayyār al-Jadīd, 2008.

Mujiburrahman. Feeling Threatened: Muslim-Christian Relations in Indonesia's New Order. Amsterdam University Press, 2006.

Mulia, Siti Musdah. "Promoting Gender Equity Through Interreligious Marriage: Empowering Indonesian Women.” In Muslim-Non-Muslim Marriage: Political and Cultural Contestations in Southeast Asia, edited by Gavin W Jones, Chee Heng Leng, and Maznah Mohamad. Singapore: ISEAS, 2009.

Nasir, Jamal J.A. The Status of Women under Islamic Law and Modern Islamic Legislation. 3rd ed. Leiden and Boston: Brill, 2009.

Nasir, Mohamad Abdun. "Religion, Law, and Identity: Contending Authorities on Interfaith Marriage in Lombok, Indonesia." Islam and Christian-Muslim Relations 31, No. 2 (2 April 2020). https://doi.org/10.108o/09596410.2020.17 73618.

Pompe, Sebastiaan. "Mixed Marriages in Indonesia: Some Comments on the Law and the Literature." Bijdragen Tot de Taal-, Land- En Volkenkunde 144, No. 2/3 (1988): 259-75.

Ramulyo, Mohd. Idris. Tinjauan Beberapa Pasal Undang-Undang Nomor 1 Tahun 1974 dari Segi Hukum Perkawinan Islam [Review of Some Articles of Law No. 1 of 1974 from the Perspective of Islamic Marriage Law]. Jakarta: IHC, 1986.

Riḍā, Muhạammad Rashīd. Tafsīr al-Qur'ān al-ḥakìm (Tafsīr al-Mannār) [Commentary on al-Qur'an (al-Mannār Commentary)]. Vol. 6. 12 vols. Cairo: Dār al-Mannār, 1947.

Rusli, and R. Tama. Perkawinan antar Agama dan Masalahnya sebagai Pelengkap UU Perkawinan No. 1 Th. 1974 [Interreligious Marriage and its Problem as an Addition to the Marriage Law No. 1 of 1974]. Bandung: Shantika Dharma, 1984. Sapir, Gideon, and Daniel Statman. "Religious Marriage in a Liberal State." In Constitutional Secularism in an Age of Religious Revival, edited by Susanna Mancini and Michel Rosenfeld, 269-82. Oxford: Oxford University Press, 2014. https://doi.org/10.1093/acprof:oso/9780199660384.003.0015. 
Sezgin, Yüksel. Human Rights under State-Enforced Religious Family Laws in Israel, Egypt and India. Cambridge Studies in Law and Society. Cambridge: Cambridge University Press, 2013. https://doi.org/10.1017/CBO9781139649612. Shachar, Ayelet. "Faith in Law? Diffusing Tensions Between Diversity and Equality." In Marriage and Divorce in a Multicultural Context: Multi-Tiered Marriage and the Boundaries of Civil Law and Religion, edited by Joel A. Nichols, 341. Cambridge: Cambridge University Press, 2012.

Simorangkir, J.C.T. "Peranserta Gereja/Warga Gereja dalam Pembangunan dan Penegakan Hukum di Indonesia dalam Hukum [The Role of Church/Church Members in the Development and the Law Enforcement in Indonesia in the Law]." In Pelaksanaan Undang-Undang Perkawinan dalam Perspektif Kristen [Implementation of the Marriage Law from the Christian Perspective], edited by Weinata Sairin and Joseph Marcus Pattiasina, 33-69. Jakarta: PT BPK Gunung Mulia, 1994.

Subekti, Valina Singka. Menyusun Konstitusi Transisi: Pergulatan Kepentingan dan Pemikiran dalam Proses Perubahan UUD 1945 [Drafting the Transitional Constitution: The Struggle of Interest and Ideas in the Process of the Amendment of the 1945 Constitution]. Jakarta: PT RajaGrafindo Persada, 2008.

Supreme Court Decree No. 1977 K/Pdt/2017 (The Supreme Court of the Republic of Indonesia, 2017).

Temperman, Jeroen. State-Religion Relationships and Human Rights Law: Towards a Right to Religiously Neutral Governance. Leiden and Boston: Martinus Nijhoff Publishers, 2010.

Tim Penyusun Naskah Komprehensif Proses dan Hasil Perubahan UUD 1945 [Drafting Team of the Comprehensive Text of the Processes and Results of the Amendment of the 1945 Constitution]. Naskah Komprehensif Perubahan Undang-Undang Dasar Negara Republik Indonesia Tahun 1945: Latar Belakang, Proses, dan Hasil Pembahasan 1999-2002, Buku VIII Warga Negara dan Penduduk, Hak Asasi Manusia dan Agama [Comprehensive Text of the Amendment of the 1945 Constitution of the Republic of Indonesia: Background, Processes, and Debates Results 1999-2002, Book VIII Citizens and Population, Human Rights and Religion]. Revised. Jakarta: Sekretariat Jenderal dan Kepaniteraan Mahkamah Konstitusi, 2010. 
“Tunisia Lifts Ban on Muslim Women Marrying Non-Muslims.” Aljazeera, 14 September 2017. https://www.aljazeera.com/news/2017/og/14/tunisia-liftsban-on-muslim-women-marrying-non-muslims/.

United States Constitution.

"Universal Declaration of Human Rights." GA Res. 217A (III), UN GAOR, UN Doc. A/810 (1o December 1948).

Yamin, Mohammad. Pembahasan Undang-Undang Dasar Republik Indonesia [Commentary on the Constitution of the Republic of Indonesia]. Jakarta: Jajasan Prapantja, 1960.

Zaydān, 'Abd al-Karīm. Aḥkām al-Żimmiyyīn wa al-Musta'minīn fì Dār al-Islām [Laws on Non-Muslims and Asylum-Seekers in the Muslim Territory]. Beirut: Mu'assasah al-Risālah and Maktabah al-Quds, 1982. 